Provided for non-commercial research and education use. Not for reproduction, distribution or commercial use.

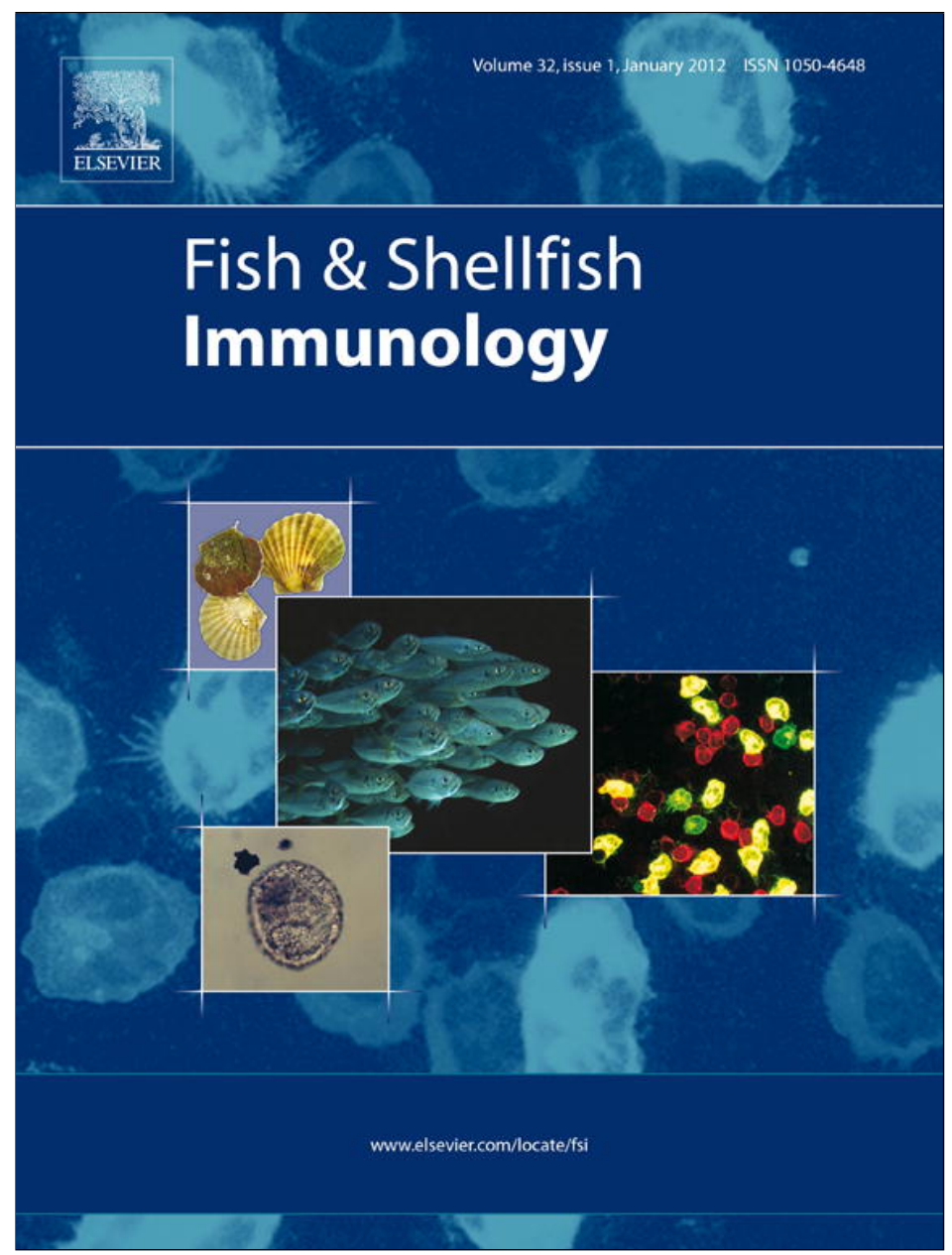

This article appeared in a journal published by Elsevier. The attached copy is furnished to the author for internal non-commercial research and education use, including for instruction at the authors institution and sharing with colleagues.

Other uses, including reproduction and distribution, or selling or licensing copies, or posting to personal, institutional or third party websites are prohibited.

In most cases authors are permitted to post their version of the article (e.g. in Word or Tex form) to their personal website or institutional repository. Authors requiring further information regarding Elsevier's archiving and manuscript policies are encouraged to visit:

http://www.elsevier.com/copyright 


\title{
Inducible galectins are expressed in the inflamed pharynx of the ascidian Ciona intestinalis
}

\author{
Aiti Vizzini, Daniela Parrinello, Maria Antonietta Sanfratello, Giuseppina Salerno, \\ Matteo Cammarata, Nicolò Parrinello* \\ Department of Environmental Biology and Biodiversity, Laboratory of Marine Immunobiology, University of Palermo, Via Archirafi 18, 90123 Palermo, Italy
}

\section{A R T I C L E I N F O}

\section{Article history:}

Received 26 May 2011

Received in revised form

14 October 2011

Accepted 23 October 2011

Available online 7 November 2011

\section{Keywords:}

Ciona intestinalis

Galectins

Hemocytes

Inflammation

Pharynx

\begin{abstract}
A B S T R A C T
Although ascidians belong to a key group in chordate phylogenesis, amino acid sequences of Ciona intestinalis galectin-CRDs (CiLgals-a and -b) have been retained too divergent from vertebrate galectins. In the present paper, to contribute in disclosing Bi-CRD galectin evolution a novel attempt was carried out on CiLgals-a and -b CRDs phylogenetic analysis, and their involvement in ascidian inflammatory responses was shown. CiLgals resulted aligned with Bi-CRD galectins from vertebrates (Xenopus tropicalis, Gallus gallus, Mus musculus, Homo sapiens), cephalochordates (Branchiostoma floridae), echinoderms (Strongylocentrotus purpuratus) and a mono-CRD galectin from the ascidian Clavelina picta. The CiLgalsa N-terminal and C-terminal CRDs contain the signature sequence involved in carbohydrate binding, whereas the CiLgals-b C-CRD presents only three out of seven key aminoacids and it could not be suitable as sugar binding motif. Sequence similarity between clusters suggests an evolutionary model based on CRD domain gene duplication and sequence diversification. In particular CiLgals-b N-CRD and C-CRD were similar to each other and both grouped with the ascidian C. picta mono-CRD. Homology modeling process shows a CiLgals molecular structure superimposed to chicken and mouse galectins. The CiLgals$a$ and CiLgals-b genes were upregulated by LPS inoculation suggesting that they are inducible and expressed in the inflamed pharynx as revealed by real-time PCR analysis. Finally, in situ hybridization and immunohistochemical assays showed their localization in the inflamed tissues, while immunoblotting analysis indicated that CiLgals can form oligomers.
\end{abstract}

(C) 2011 Elsevier Ltd. All rights reserved.

\section{Introduction}

Galectins, Ca-independent and formerly named S-lectins [1], possess a relatively high affinity to $\beta$-galactosides and are grouped in a protein family, characterized by homologous carbohydrate recognition domains (CRD). All galectins contain either one or two evolutionary conserved CRDs [2], and have been distinguished into three groups: (1) prototype galectins (one CRD); (2) tandem type galectins, composed of two CRDs, homologous but not identical, connected by a short linker peptide (Bi-CRD); and (3) chimeric type galectins (one CRD and one regulatory domain). The vertebrate BiCRD galectins are always encoded by three exons with two subtypes: N-terminal F4 subtype CRD and the C-terminal F3 subtype CRD (F4-CRDs and F3-CRDs) [3]. Also the exon/intron organization of the echinoderm Strongylocentrotus purpuratus and the amphioxus Branchiostoma belcheri galectins [3] is very similar

\footnotetext{
* Corresponding author. Tel.: +39091 23891821; fax: +3909123860855.

E-mail address: nicolo.parrinello@unipa.it (N. Parrinello).
}

to their vertebrate orthologues. Galectins are mainly cytosolic, and exert extracellular functions by the binding to and cross-linking of glycan groups of glycoproteins and/or glycolypids on the surface of various cell types [4]. They are involved in numerous biological processes including immune responses $[2,5,6,7]$.

Since ascidians are considered a key group in chordate phylogenesis $[8,9]$ and have recently been considered the sister group of vertebrates $[10,11]$, studies on inducible ascidian galectins may shed light on the evolutionary emergence of inflammatory molecules. In mammals, galectins are retained proinflammatory cytokines released when immune responses are triggered [7]. Therefore, ascidian inflammatory reaction is a suitable model to examine inducible cytokine-like factors, and represents a functional approach to see the galectin involvement in ascidian innate immunity. In this respect, Styela plicata C-type lectins are components of the acute-phase response [12], a Clavelina picta prototype galectin has been sequenced [5], and a Didemnum candidum galactosyl-binding lectin is provided with mitogenic activity vs. murine thymocytes [16]. The genome-wide analysis of Ciona intestinalis has provided a comprehensive picture of immune-related genes and the annotated galectin 
genes appeared to be expressed by unchallenged hemocytes [13-15]. The sequences of two $C$. intestinalis genes encoding bi-CRD galectins (CiLgals-a and CiLgals-b) have been deducted from ESTs and genome [17]. The CiLgals-a exhibits F4-CRD-liker-F3-CRD organization typical of all vertebrate $\mathrm{Bi}-\mathrm{CRD}$ galectin genes. Conversely, although the genomic sequence of the CiLgals-b encoding gene was still incomplete, Houzelstein et al. [17] reported that it shows an F4-CRD-linkerF4-CRD structure not known in vertebrate genes. However, these authors were not able to include the CiLgals CRD amino acid sequences in an inclusive phylogenetic tree formed with vertebrate galectins, and stated that they were too divergent. Therefore, a novel attempt focused on searching sequence similarity could contribute in disclosing the Bi-CRD galectin molecular evolution. Moreover, since the immune function of $B$. belcheri galectins consistent with its cytolocalization has been established [3], the question arises about whether and how ascidian Bi-CRD galectin genes expression can be induced by microbial agents and involved in innate immunity.

In the previous papers we reported that inflammatory responses can be induced in the $C$. intestinalis body wall [18-20] and showed the involvement of the pharynx in producing inflammatory molecules as a response to bacterial wall lipopolysaccharide (LPS) inoculation [21-26]. In particular the hemolymphatic level of galectin-like molecules with opsonic property could be increased following an LPS treatment [27]. In the present paper further insight emerges from the CRD phylogenetic analysis, in addition we show that the CiLgals-a and CiLgals-b genes can be upregulated. Both galectins appear to be inducible and promptly expressed in the pharynx after LPS was inoculated. Finally, in situ hybridization (ISH) and immunohistochemical assays showed their localization in the inflamed pharynx tissues, and immunoblotting analysis suggests that each of them can form oligomers.

\section{Materials and methods}

\subsection{Ascidians, LPS inoculation and sample preparation}

Ascidians were gathered from Termini Imerese marinas (Italy), maintained in aerated seawater at $15{ }^{\circ} \mathrm{C}$ and fed every second day with a marine invertebrate diet (Coraliquid, Sera Heinsberg, Germany). Before any treatment the tunic surface was cleaned and sterilized with ethyl alcohol.

LPS (Escherichia coli 055:B5, LPS, Sigma-Aldrich, Germany) was prepared in sterile marine solution (MS: $12 \mathrm{mM} \mathrm{CaCl} \cdot 6 \mathrm{H}_{2} \mathrm{O}$, $11 \mathrm{mM} \mathrm{KCl}, 26 \mathrm{mM} \mathrm{MgCl}_{2} \cdot 6 \mathrm{H}_{2} \mathrm{O}, 43 \mathrm{mM}$ Tris $\mathrm{HCl}, 0.4 \mathrm{M} \mathrm{NaCl}, \mathrm{pH}$ 8.0). As previously described [21,23], $100 \mu \mathrm{g}$ LPS in $100 \mu \mathrm{l}$ MS per specimen were inoculated through the body wall (middle region of the longitudinal axis) just under the tunic to allow the local spread into the pharynx tissue. Then, at various time points, a constant amount of pharynx tissue was excised from the body wall at the injection site. Ascidians either untreated (naïve) or injected with $100 \mu \mathrm{l}$ MS (sham) were used as a control.

To prepare pharynx homogenate supernatant, the pieces of tissue (200 mg/ascidian) were homogenized on ice in lysis buffer (sodium deoxycholate $10 \mathrm{mM}, \mathrm{pH} 8 ; 1 \mathrm{ml} / \mathrm{g}$ ) by an high-performance disperser (Ultra-Turrax). The supernatant, separated by centrifuging the homogenate at $13,000 \mathrm{~g}$ for $30 \mathrm{~min}$ at $4{ }^{\circ} \mathrm{C}$, was mixed (1:200) with a protease inhibitor cocktail (pepstatin A, E-64, bestatin, leupeptin, aprotinin, and AEBSF) and stored at $-80^{\circ} \mathrm{C}$.

\subsection{Total RNA extraction, $C D N A$ and riboprobe synthesis}

Pieces of pharynx ( $200 \mathrm{mg} /$ ascidian) excised at various time points p.i. (from 1 to $72 \mathrm{~h}$ ) were immediately soaked in RNAlater Tissue collection (Ambion, Austin, TX) and stored at $-80^{\circ} \mathrm{C}$. Total RNA was isolated by using an RNAqueous ${ }^{\mathrm{TM}}$-Midi Kit purification system (Ambion) and reverse-transcribed by the Cloned AMV FirstStrand cDNA Synthesis Kit (Invitrogen). To produce specific probes, primer pairs were designed on the annotated CiLgals-a (Ensembl ID: ENSCINT00000017930) and CiLgals-b (Ensembl ID: ENSCINT00000004710) sequences (Table 1). The riboprobes contained the C-CRD ( $C$ terminus) sequence between the positions 621-1223 of CiLgalsa cDNA and the positions 610-1331 of CiLgals-b cDNA. Amplified cDNA was produced by reverse-transcription of mRNA from pharynx at $4 \mathrm{~h}$ after the LPS injection. A PCR reaction was performed using AmpliTaq Gold DNA Polymerase (Applied Biosystems). The amplification procedure was as follows: 2 min initial denaturation at $95{ }^{\circ} \mathrm{C}$ followed by 30 cycles consisting of $95^{\circ} \mathrm{C}$ for $30 \mathrm{~s} ; 1 \mathrm{~min}$ at the respective annealing temperatures, $72{ }^{\circ} \mathrm{C}$ for $1 \mathrm{~min}$ and a final extension at $72{ }^{\circ} \mathrm{C}$ for $7 \mathrm{~min}$. The amplification product was cloned into the $\mathrm{pCR}^{\mathrm{TM}}$ IIvector (TA cloning Kit, Invitrogen) and sequenced. To determine the nucleotide sequence, suitable amounts of lyophilized samples were analyzed by the Biotechnology Centre, University of Padua, Italy. (http://bmr.cribi.unipd.it, ABI PRISM-DNA sequences, Applied Biosystems). The obtained sequences (CiLgals-a and -b) were consistent with sequences annotated in Ensembl and were utilized for digoxigenin-11-UTP-labeled riboprobes synthesis (Roche Diagnostics).

\subsection{Phylogenetic and structural analysis}

Sequences related to CiLgals-a and CiLgals-b from invertebrate deuterostomes (the echinoderm S. purpuratus, the coephalocordate B. floridae, the ascidian C. picta) and vertebrate species (Xenopus tropicalis, Gallus gallus, Mus musculus, Homo sapiens) were subjected to multiple alignments using the Clustal W program [28]. The final sequence alignment was done using CLUSTAL W v.1.81 [29] and the similarity shaded with GeneDoc v.2.6.002. A phylogenetic tree was constructed by the Neighbor-Joining method (NJ) after 1000 bootstrap iterations by using CLC workbench 6.4. The respective GenBank accession numbers were as follows: $H$. sapiens LGal9 (BAB83625.1), G. gallus Lgal 8 (ABD97855.1), B. floridae Lgal (EEN66300.1), M. musculus Lgal 6 (NP_034837.1), X. tropicalis Lgal 4 (AAH88541.1), C. picta Gal 16 (ABV46595.1), S. purpuratus RL30 (XP_781871.1). The protein structural models were developed with SWISS-MODEL and the Swiss-PdbViewer [30-32].

\subsection{Real-time PCR analysis}

CiLgalsa-a and CiLgals-b genes expression was detected by realtime PCR using the Taqman method as previously described [23]. The expression was performed using CiLgals-a probe (AACTTCGCTCACCGTTT), forward primer (5'-TGTTGAATGGCTTCCACTTGTT- $3^{\prime}$ ) and reverse primers ( $5^{\prime}$-TCGGATGTTACGCAGAGGTTT- $\left.3^{\prime}\right)$, CiLgalsb probe (CTTCTGCGACTTCACA), forward primer (5'-CTCGGTGTATGTGAACGATGTTC- $3^{\prime}$ ) and reverse primers (5'-CGGTAGAGCGGCACCTTGT-3'), actin probe (TCGACAATGGATCCGGT), actin forward ( $5^{\prime}-$ TGATGTTGCCGCACTCGTA- $3^{\prime}$ ) and reverse (5'-TCGACAATGGATCCGGT-3') primers. Each set of samples was run three times and each plate contained quadruplicate cDNA samples and negative controls. The amplification efficiency of the target and reference genes was approximately equal validating the $\Delta \Delta \mathrm{Ct}$ calculation. To compensate

Table 1

Primers used.

\begin{tabular}{ll}
\hline Primer & Sequence \\
\hline CiLgals-b forward primer & $5^{\prime}$-ACAAGTTTGGGTTCAACTAC-3' \\
CiLgals-b reverse primer & $5^{\prime}$-TAACGTCCAGCATGTAAGTA-3' \\
CiLgals-a forward primer & $5^{\prime}$-GAAACTCGTTACTGGACAAC-3' \\
CiLgals-a reverse primer & $5^{\prime}$-AGTACCCTGCTTATCTATGCT-3' \\
\hline
\end{tabular}


for variations in input RNA amounts, the CiLgals-a and CiLgalsb transcripts from different samples were normalized to actin. The relative expression was determined by dividing the normalized value of the target gene in each sample by the normalized value obtained from the untreated tissue.

\subsection{Production of specific antibodies against CiLgals- a and CiLgals- $b$ peptides}

Antibodies were raised against peptides selected from the mature CiLgals-a and CiLgals-b sequences and provided of adequate immunogenic properties (Sigma-Genosys, UK). Peptide synthesis and antiserum production were performed by Sigma-Genosys. Briefly, the peptides (CiLgals-a DTGIEIPKPAVDTL-C and CiLgalsb MFRTQRKLNRPAI-C) designed on the deduced amino acid sequences (CiLgals-a and CiLgals-b) were used to immunize rabbits through a suitable immunization schedule (proprietary protocol). The rabbit serum antibody titer $(1: 25,000)$ was recorded by ELISA with the synthetic peptide as an antigen. ELISA of the rabbit preimmune serum excluded the presence of unspecific reaction.

Specific antibodies were isolated by affinity chromatography as follows. The peptide ( $5 \mathrm{mg}$ ) was coupled to $20 \mathrm{ml}$ of CNBr-activated Sepharose 4B (GE Healthcare) according to the manufacturer's instructions. Filtered $(0.45 \mu \mathrm{m}$ filter $)$ rabbit serum $(25 \mathrm{ml})$ was passed through a Sepharose-peptide column $(1 \times 5 \mathrm{~cm})$, then the column was extensively washed with PBS until the absorbance $(280 \mathrm{~nm})$ baseline was reached. Adsorbed antibodies were eluted with $0.1 \mathrm{M}$ glycine- $\mathrm{HCl} \mathrm{pH} 2.8$ and the fractions were collected in $100 \mu \mathrm{l}$ of $1 \mathrm{M}$ Tris $\mathrm{pH} 8$, pooled and dialyzed against PBS. Antibody titer of the pooled samples (CiLgals-a $0.170 \mathrm{mg} / \mathrm{ml}$ or CiLgalsb $0.65 \mathrm{mg} / \mathrm{ml}$ protein content) was checked by ELISA.

\subsection{Antibody specificity: indirect peptide ELISA and competitive ELISA}

ELISA was performed as described by Plagemann [33]. In brief, the wells of Nunc Maxisorp ELISA plates (Nunc, Denmark) were coated overnight with the peptide $(10 \mu \mathrm{g} /$ well) dissolved in carbonate buffer, pH 9.6. After peptide coating, the wells were rinsed with PBS containing $0.1 \%(\mathrm{v} / \mathrm{v})$ Tween 20 (PBS-T), and then incubated with the blocking buffer ( $1 \% \mathrm{w} / \mathrm{v}$ BSA in PBS-T) at r.t. for $1 \mathrm{~h}$. Then, the wells were incubated with: (1) anti-CiLgals-a and anti-CiLgals-b antisera diluted (1:1000-1:50,000) in blocking solution; (2) pre-immune rabbit serum in blocking solution (1:50-1:200); (3) purified antibody fraction diluted in blocking solution $(1: 1000-1: 50,000)$ at r.t. for $1 \mathrm{~h}$. After rinsing with PBS-T the wells were incubated (at r.t. for $60 \mathrm{~min}$ ) with peroxidase-conjugated anti-rabbit IgGs diluted 1:10.000 in blocking solution, rinsed four times with PBS-T and then incubated (15-30 min) with 0 -phenylenediamine ( $2 \mathrm{mg}$ in sodium citrate $0.1 \mathrm{M}, \mathrm{pH} 4.0)$ substrate $(100 \mu \mathrm{l} /$ well). The peroxidase product was quantified by recording absorbance at $492 \mathrm{~nm}$ with an automatic plate reader.

Antibody specificity was further checked as follows (competitive ELISA) [33]: (1) $100 \mu \mathrm{l} /$ well specific antibody preparation diluted 1:3000 or 1:5000 in PBS-T and $10 \mu \mathrm{g}$ CiLgals-a peptide or CiLgals-b peptide/well (competitive ELISA) were incubated in the peptide-coated wells. (2) Anti-CiLgals-a-peptide and Anti-CiLgals$b$-peptide antibodies (diluted from 1:1000 to 1:50,000) were incubated, respectively, in the CiLgals-b and CiLgals- $a$ peptidecoated wells. Then the above reported procedure was used.

\subsection{Western blot analysis}

SDS-PAGE (12\% acrylamide) of pharynx homogenate supernatant containing $2 \mu \mathrm{g}$ protein was carried out according to the method of Laemmli [34]. The sample was prepared in reducing sample buffer, then the gel was soaked in transfer buffer $(20 \mathrm{mM}$ Tris, $150 \mathrm{mM}$ glycine, $\mathrm{pH} 8.8$ ) for $10 \mathrm{~min}$ and proteins were transferred ( $1 \mathrm{~h}$ at $210 \mathrm{~mA}$ ) to a nitrocellulose sheet in transfer buffer. The filter was soaked for $2 \mathrm{~h}$ in blocking buffer (PBS containing $2 \%$ BSA and $0.05 \%$ Tween-20), incubated with anti-CiLgals-a and antiCiLgals-b antibodies diluted in blocking solution (1:1000) for $1 \mathrm{~h}$, washed with blocking buffer, and incubated for $1 \mathrm{~h}$ with anti-rabbit IgG-alkaline phosphatase conjugate (1:20,000 in blocking buffer). After washing with PBS, the nitrocellulose sheet was treated with 5-bromo-4-chloro-3-indolyl phosphate/nitro blue tetrazolium (BCIP/NBT) liquid substrate system $(3 \mathrm{ml})$.

\subsection{In situ hybridization (ISH) and immunohistochemistry (IH)}

For histological studies, 10 ascidians inoculated with LPS either at $4 \mathrm{~h}$ or $24 \mathrm{~h}$ p.i. were examined by in situ hybridization (ISH) and an equal number of ascidians by immunohistochemistry ( $\mathrm{IH})$. Five naïve and 5 sham ascidians were used as controls. Tissues were fixed in Bouin's fluid (saturated picric acid: formaldehyde:acetic acid 15:5:1) for $24 \mathrm{~h}$, paraffin embedded and serially cut at $6 \mu \mathrm{m}$ (Leica RM2035 microtome, Solms, Germany). Histological sections were examined under a Leica DMRE microscope and tissues identified as reported in previous papers $[21,23]$.

The ISH method has been previously reported [21,23]. In brief, histological sections were treated with digoxigenin-11-UTPlabeled riboprobes $(1 \mu \mathrm{g} / \mathrm{ml}$ final concentration) (Roche Diagnostics). After digestion with proteinase $\mathrm{K}(10 \mu \mathrm{g} / \mathrm{ml})$ in PBS-T for $5 \mathrm{~min}$, sections washed with PBS-T1 were treated with hybridization buffer containing $50 \%$ formamide, $5 \times$ SSC $(1 \times$ SSC: $0.15 \mathrm{M}$ $\mathrm{NaCl} / 0.015 \mathrm{M}$ sodium citrate, $\mathrm{pH} 7), 50 \mu \mathrm{g} / \mathrm{ml}$ heparin, $500 \mu \mathrm{g} / \mathrm{ml}$ yeast tRNA and $0.1 \%$ Tween 20 , at $37^{\circ} \mathrm{C}$ overnight. After $1 \mathrm{~h}$ incubation with anti-DIG-Fab-AP conjugate (Roche Diagnostics) diluted 1:100, the sections were washed in PBS-T and finally incubated in 5-bromo-4-chloro-3-indolyl phosphate/nitro blue tetrazolium (BCIP/NBT) liquid substrate system (Sigma-Aldrich, Germany). Color development was stopped after 30 min at r.t. The prehybridization was carried out in the hybridization buffer for $1 \mathrm{~h}$ at $37^{\circ} \mathrm{C}$.

For immunohistochemistry study (IH), histological sections washed in PBS-T were incubated with 3\% BSA in PBS-T for $2 \mathrm{~h}$ at r.t., and then (overnight at $\left.4{ }^{\circ} \mathrm{C}\right)$ with primary antibody $(0.0170 \mu \mathrm{g} / \mu \mathrm{l}$ anti-Ci-Lgals-a, $0.026 \mu \mathrm{g} / \mu \mathrm{l}$ anti-CiLgals-b) in PBS-T/1\% BSA. Antirabbit IgG phosphatase alkaline conjugated antibody was used as secondary antibody $(1: 10,000 ; 90 \mathrm{~min}$ at r.t.). The sections were rinsed with PBS-T and stained with BCIP/NBT liquid substrate system. Hemocyte types were identified according to Arizza and Parrinello [35].

\subsection{Estimation of protein content and chemicals}

Protein content was measured according to the method of Bradford [36] using BSA as a standard.

Unless otherwise mentioned, chemicals and secondary antibodies were from Sigma-Aldrich (Germany).

\subsection{Statistical methods}

Student's t-test was used to estimate statistical significance. Multiple comparisons were performed with one-way analysis of variance (ANOVA), and different groups were compared by using Tukey's $t$-test. Standard deviations were calculated on four experiments. $P<0.01$ was considered statistically significant. 


\section{Results}

\subsection{Phylogenetic analysis}

The CiLgals-a and a CiLgals-b amino acid sequences were identified in Ensembl. The CiLgals-a predicted gene (ID ENSCING00000008811) was found to be localized on the chromosome 4q: 4,832,720-4,836,516, and the CiLgals-b predicted gene (ID ENSCING00000015311) on the chromosome 6q: 303,057-309,579. The CiLgals-a transcript (1285 bp) encodes a 289 aminoacid sequence with a deduced molecular size of $32.9 \mathrm{kDa}$, and the CiLgals-a transcript (1332 bp) encodes a 318 aminoacid sequence with a $37.1 \mathrm{kDa}$ deduced molecular size.

By comparing the overall deduced amino acid sequences the major similarity (SP) and identity percentages (IP) were found among Ciona galectins and the overall sequences of chicken Galectin 8 (GenBank ID: Q1W2P6) and mouse Galectin 6 (GenBank ID: 054891). The CiLgals-a presented 66.6\% SP and 34.1\% IP to Gal 8, and the CiLgals-b showed 47.6\% SP and 23.6\% IP to Gal 6.

The CiLgals-a and CiLgals-b CRD sequences were aligned with vertebrate bi-CRD galectins (X. tropicalis Gal4, G. gallus Gal8, M. musculus Gal6, H. sapiens Gal9), the cephalochordate B. floridae, the ascidian $C$. picta mono-CRD gal16, and the echinoderm S. purpuratus gal RL30 galectin (Fig. 1). The following items could be drawn from the phylogenetic tree (Fig. 2). (1) In both CiLgals-a and -b, two CRDs (N-terminal CRD and C-terminal CRD) were recognized; (2) CiLgals-a N-CRD and C-CRD were similar to each other, and both form a cluster with the aligned vertebrate C-CRDs; (3) the echinoderm N-CRD and C-CRD as well as the amphioxus N-CRD and C-CRD, were similar to each other and both were grouped with the aligned vertebrate N-CRDs; (4) CiLgals-b N-CRD and C-CRD were similar to each other and both grouped with the $C$. picta mono-CRD Gal16; and (5) the G. gallus Gal8N-CRD was close to the echinoderm and amphioxus $\mathrm{N}$-CRDs and C-CRDs, and they all form a wider cluster with the vertebrate N-CRDs.

The alignments presented in Fig. 1 show the conserved amino acid residues that were identified (European Bioinformatics Institute EBI interpro databanks) as the galectin sequence motif ( $\mathrm{H}$ NPRN and WG-EE). Seven of this signature aminoacids are known to be directly involved in galactoside binding (H-N-R N W- -EE). In CiLgals-a, the seven key residues are conserved in the N-CRD whereas in the C-CRD one key residue is substituted in a conservative way (R-K) (Fig. 1). On the contrary CiLgals-b shows only five conserved key residues in the N-CRD, the changes include one conservative substitution (D-E) and a not conservative one $(E-R)$. The CiLgals-b C-CRD was more divergent; it showed only three out

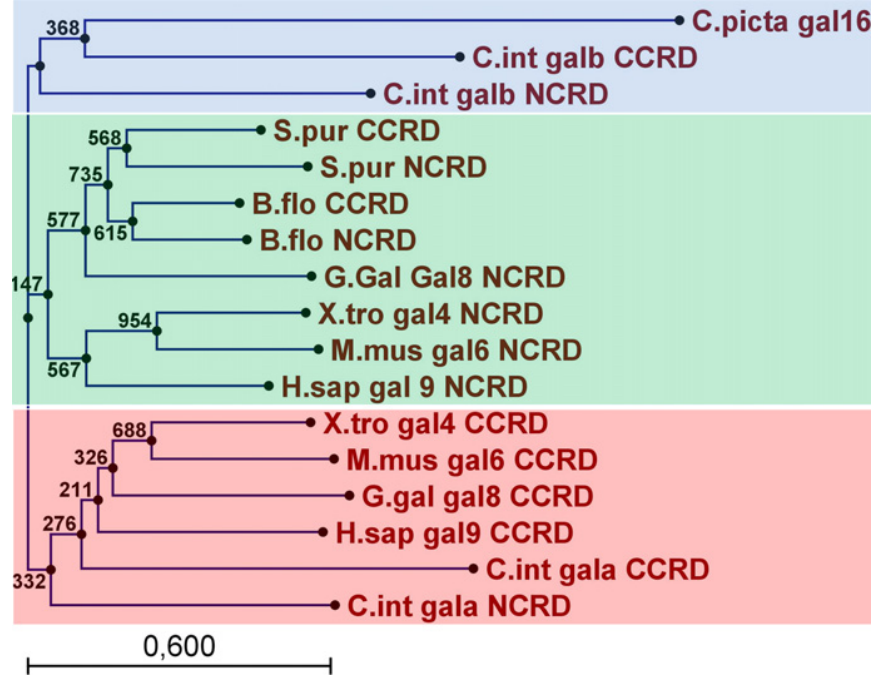

Fig. 2. Phylogenetic tree of CRDs from CiLgals-a, CiLgals-b, vertebrate bi-CRD galectins amino acid sequences (C.picta: C. picta; C.int: C. intestinalis; S.pur; S. purpuratus; B.flo: B. floridae; G.gal: G. gallus; X.tro: X. tropicalis, M.mus: M. musculus H.sap: H. sapiens). The tree was constructed by the neighbor-joining method and bootstrap analysis. Bootstrap value indicates the percentage of time that the particular node occurred in 1000 trees generated by bootstrapping the galectin CRD sequences. Bar 0.600 (number of amino acid residues substitutions for site).

of seven key aminoacids in its C-CRD (Fig. 1). The key tryptophan was found both in CiLgals-a and -b CRD signature sequences.

Fig. 3 shows the molecular models by the homology modeling process performed on the basis of the known galectin molecular structures. The 120-127 amino acid long CiLgals-a and -b CRDs appeared to consist of two structurally conserved anti-parallel $\beta$ sheets, composed of five and six $\beta$-strands (labeled F1 to F5 and S1 to S6). The CiLgals-a N-CRD was superimposed to the Human Gal 9 C-CRD (swissprot 3nv1A, 39.85\% identity, three cysteins), the CiLgals-a C-CRD on the Human Gal 3 C-CRD (swissprot $2 \times$ g3A, 29.71\% identity); CiLgals-b N-CRD was superimposed to the Human Gal 9N-CRD (swissprot 2zhnA, 30.35\% identity, 1 cystein); CiLgals-b CCRD was modeled on the Human Gal 4 C-CRD (swissprot $1 \times 50$ A, $27.40 \%$ identity, 4 cysteins).

\subsection{CiLgals genes are upregulated in inflamed pharynx}

Real-time PCR analysis of the inflamed ascidian pharynx showed enhanced CiLgals-a and CiLgals-b mRNA levels as an effect of the

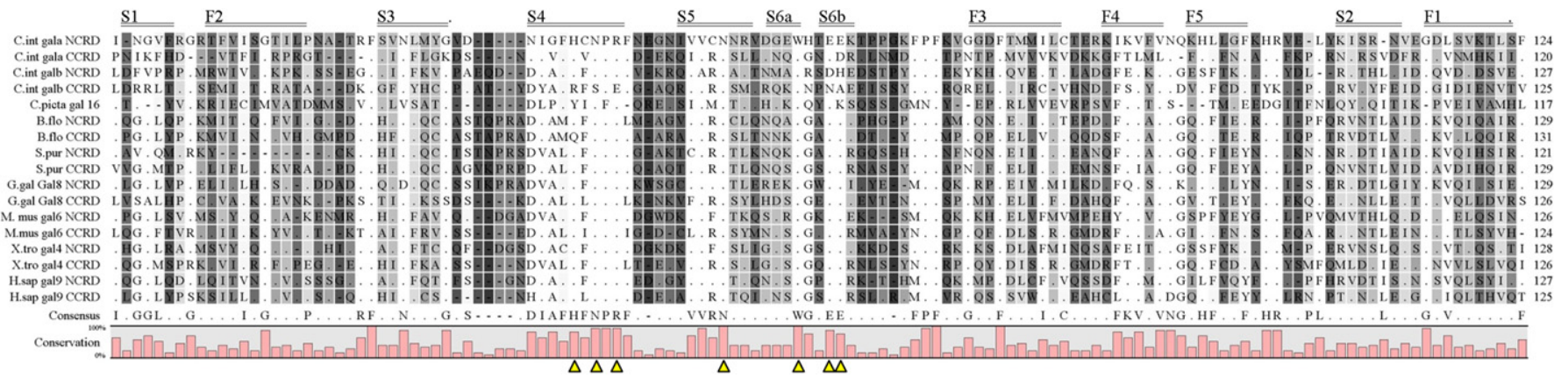

Fig. 1. Alignment of CiLgals-a and CiLgals-b CRDs with vertebrate bi-CRD galectins (Xenopus tropicalis Gal4, Gallus gallus Gal8, Mus musculus Gal6, Homo sapiens Gal9), the cephalochordate Branchiostoma floridae, the ascidian Clavelina picta mono-CRD gal16, and the echinoderm Strongylocentrotus purpuratus gal RL30 galectin. The position of five and six $\beta$-strands (labeled F1 to F5 and S1 to S6) that composed two structurally conserved anti-parallel $\beta$-sheets are indicated. Yellow triangles indicate the seven conserved amino acids known to interact with bound galactosides. The conservation of amino acid is represented by letter background gray gradients. (For interpretation of the references to color in this figure legend, the reader is referred to the web version of this article.) 


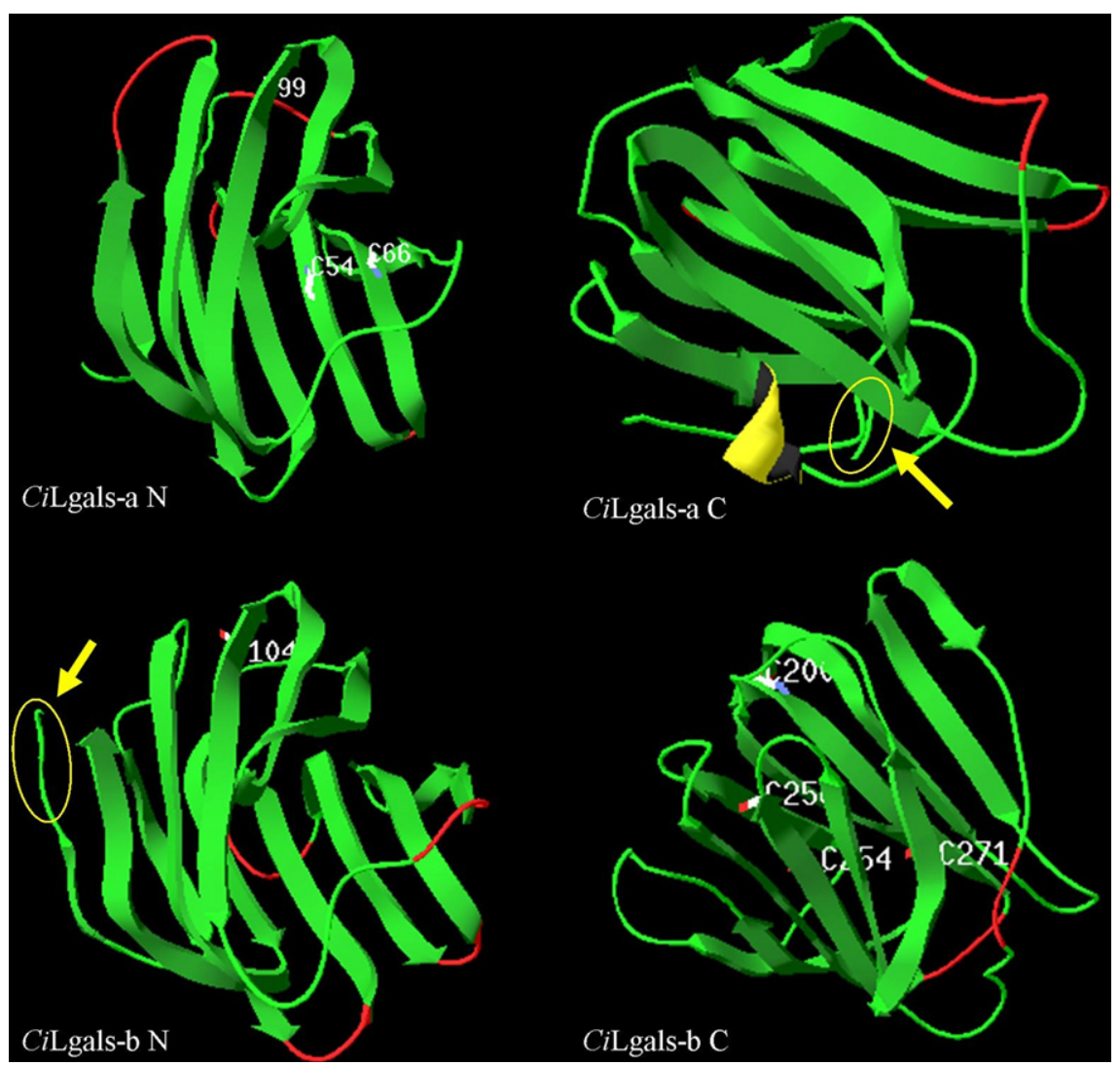

Fig. 3. The CiLgals-a, CiLgals-b CRDs of Ciona intestinalis were modeled with the more structural significant template of galectin domains. CiLgals-a N-terminal: 3nv1A (Human Gal 9 C-Terminal CRD 39.85\% identity); CiLgals-a C-terminal: $2 \times$ g3A (Human Gal $329.71 \%$ identity); CiLgals-b N-terminal: 2zhnA (Human Gal 9N-Terminal CRD 30.35\% identity); CiLgalsb C-terminal 1×50A (Human Gal 4 C-Terminal CRD 27.40\% identity). The homology is shown in green, the differences are stained in red, helices in yellow. The cysteins were indicated by white position numbers. (For interpretation of the references to color in this figure legend, the reader is referred to the web version of this article.)

LPS inoculation (Fig. 4). To examine the time-course of the response, four ascidians in three distinct experiments were examined at different post-inoculation time points $(1,2,4,8,12,24,48$, $72 \mathrm{~h}$ p.i.) and compared with naïve and sham ascidians sampled at the same time points. Naïve ascidians disclosed a low expression level that was constantly maintained at the growing interval time until the end of the experiment. Ascidians just inoculated with LPS (time 0) presented mRNA level at a control level.

Although similar CiLgals-a and CiLgals-b real-time PCR profiles were found following MS or LPS inoculation, the CiLgals-a mRNA expression was overall higher than that of CiLgals-b. After LPS inoculation the CiLgals-a gene expression was boosted at $12 \mathrm{~h}$ reaching a maximum at $24 \mathrm{~h}$ p.i. and the relative values were significantly higher than those recorded in the controls. The CiLgals-b gene expression quickly increased at $1 \mathrm{~h}$ p.i. but peaked at $24 \mathrm{~h}$ p.i. when significant differences with the controls were observed. At $72 \mathrm{~h}$ p.i. both CiLgals-a and CiLgals-b gene expressions were significantly lowered.

\subsection{CiLgals- $a$ and CiLgals-b genes are expressed by pharynx hemocytes}

Histological sections from ascidians at $4 \mathrm{~h}$ and $24 \mathrm{~h}$ p.i. were examined. In situ hybridization assays disclosed that hemocytes into pharynx vessels expressed CiLgals-a (Fig. 5a-d) and CiLgalsb (Fig. 5; e-h) mRNAs. Positive cells grouped in small cluster were scattered in the vessel lumen at $4 \mathrm{~h}$ (Fig. $5 \mathrm{~b}$ and $\mathrm{f}$ ) but they were mainly abundant at $24 \mathrm{~h}$ p.i. when most of the hemocytes were marked (Fig. $5 \mathrm{c}$ and g). Few clusters were found both in naïve (not shown) and MS-treated ( $24 \mathrm{~h}$ ) ascidians (Fig. $5 \mathrm{a}$ and e). The positive hemocytes were univacuolar (signet-ring-like, Fig. 5 h inset 1 ) or multivacuolar cells (Fig. 5d inset, and h insets 1,2 ), many of them showed features of compartment cells. The riboprobes appeared to be mainly localized in a position occupied by the nucleus and in the surrounding cytoplasm (Fig. 5d and h).

\subsection{Specific antibodies identify CiLgals- $a$ and CiLgals- $b$ in western blot and in the inflamed tissue}

The homology modeling process shows that the peptide sequences used for producing specific antibodies were exposed at the surface of CiLgals-a and CiLgals-b (Fig. 3). The anti-CiLgals-a or CiLgals-b antibodies diluted up to $1: 25,000$ reacted in ELISA with the immobilized peptide. The purified anti-CiLgals-a and anti-CiLgals-b antibodies reacted up to $1: 10,000$ and $1: 25,000$ antibody dilutions, respectively. Competitive ELISA, executed in the presence of the solubilized peptides $(10 \mu \mathrm{g} / \mathrm{ml} /$ well), showed a competitive antibody inhibition which abolished the reaction with the immobilized peptide. No cross-reaction was found by crossing antibodies and peptides.

Western blot analysis with the specific antibodies was carried out to ensure that proteins with CiLgals epitopes were contained in the pharynx extract supernatants (10 ascidians) prepared at $24 \mathrm{~h}$ post-LPS inoculation. The anti-CiLgals-a reacted with 74 and $43 \mathrm{kDa}$ proteins (Fig 6, lane 2), and the anti-CiLgals-b reacted with 71 and $39 \mathrm{kDa}$ proteins (Fig 6, lane 3). A Coomassie staining of the SDSPAGE pattern, showed that the two recognized bands were not the most represented (Fig. 6, lane 1). 

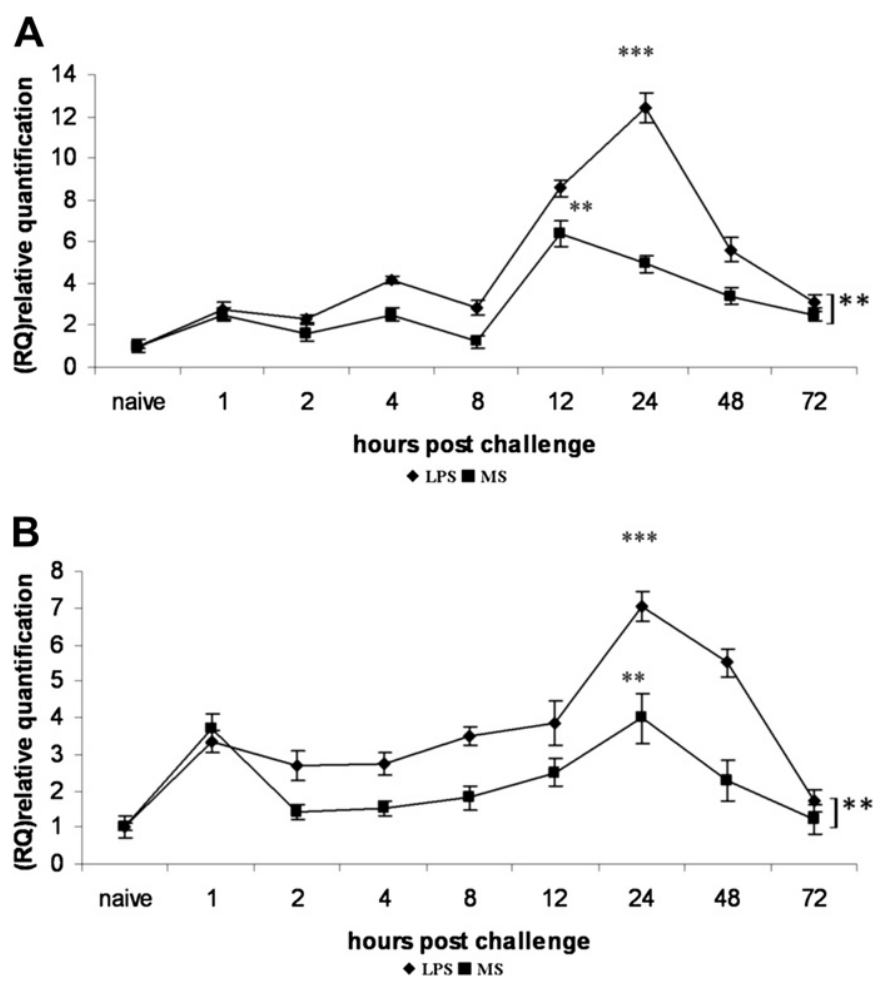

Fig. 4. Real-time PCR analysis. Time-course of CiLgals-a (A) and CiLgals-b (B) gene expression in Ciona intestinalis pharynx after inoculation into the body wall of $100 \mu \mathrm{g}$ bacterial lipopolysaccharide (LPS) in $100 \mu \mathrm{l}$ marine solution (MS) (filled diamonds), compared with the gene expression in ascidians injected with $100 \mu \mathrm{l}$ MS (filled squares). Values, plotted as mean $\pm S D$, were inferred from four ascidians examined in three distinct experiments; each assay was performed in triplicate. Significance was evaluated by comparing the values with the expression level of untreated pharynx from four ascidians (open box naïve ascidians). ${ }^{* *} P<0.01,{ }^{* * *} P<0.001$. Multiple comparisons of the time-course profiles were performed with one-way analysis of variance (ANOVA), and the different groups were compared by the Tukey $t$-test.

To examine whether CiLgals were contained in and released from the pharynx cells, immunohistochemistry observations were carried out on histological sections. A faint stain was found in sections from sham and $4 \mathrm{~h}$-treated ascidians (Fig. 5i, l, o, and p) whereas an intense staining was observed at $24 \mathrm{~h}$ p.i., more marked with the anti-CiLgals-a antibody (Fig. $5 \mathrm{~m}$ and $\mathrm{n}$ ). A weaker staining was obtained with anti-CiLgals-b antibody (Fig. 5o-r).

Although it was difficult to identify hemocyte types and protein subcellular localization by using an immunostaining method, the antibody reaction showed that at $4 \mathrm{~h}$ and mainly at $24 \mathrm{~h}$, the CiLgals-a (Fig. $5 \mathrm{~m}$ and $\mathrm{n}$ ) and CiLgals-b (Fig. 5q and r) were localized in multivacuolar (compartment) cells. Both galectins were associated to the vacuoles and nucleus envelopes (insets in Fig $5 \mathrm{n}$ and $\mathrm{r}$ ), and occasionally as components of granules (Fig. 5n and r). Moreover, both galectins appeared to be components of the endothelium basal membrane (Fig. 5n and r). Negative cells were an internal control.

\section{Discussion}

A search in the Ensembl genome browser supported the predicted $C$. intestinalis Bi-CRD galectin genes (CiLgals-a and CiLgals-b) organization [17] and showed the chromosome localization (Chromosome 4q and Chromosome 6q, respectively).

The CiLgals-a exhibits the F4-CRD-linkers-F3-CRD arrangement typical of the vertebrate Bi-CRD Lgals genes that we also found in sea urchin $S$. purpuratus and amphioxus $P$. floridae galectins. Their sequences do not contain a signal peptide and it is reasonable that, as reported for vertebrates, cytosolic galectins are released through a non-classical secretory pathway escaping the endoplasmic reticulum and Golgi apparatus [37-39]. The CiLgal-b presents a specific F4-CRD-linker-F4-CRD organization.

To give further insight on CiLgals-CRDs phylogenetic relationships, the candidate CRD sequences were evaluated according to an explicit optimality criterion. The phylogenetic tree with the most favorable score was taken as the best estimate of the relationships. A domain duplication model [5] emerges by comparing the N-CRD and C-CRD amino acid sequences. Vertebrate N-CRDs and C-CRDs are grouped into two distinct clusters indicating an early domain divergence. The N-CRD lineage includes S. purpuratus and B. floridae $\mathrm{N}-\mathrm{CRD}$ and C-CRD, while the C-CRD lineage includes CiLgals-a CCRD and $\mathrm{N}-\mathrm{CRD}$ indicating that the divergence between vertebrate $\mathrm{N}-\mathrm{CRD}$ and $\mathrm{C}-\mathrm{CRD}$ was greater than that between $\mathrm{N}-\mathrm{CRD}$ and $\mathrm{C}-\mathrm{CRD}$ of the examined deuterostome invertebrates. Further analyses, including functional ones, are needed to explain the relationships between vertebrate N-CRDs and Bi-galectins from S. purpuratus and B. floridae as well as between vertebrate C-CRDs and the CiLGglsa galectin. The relationship between CiLgals-b and the mono-CRD C.picta Gal 16 supports that a duplication event could be claimed to explain the origin of ascidian Bi-CRD galectins. This is in accordance to Houzelstein et al. [17] that hypothesized a mono-CRD (F4 subtype) as the original form of the Bi-CRDs. An F4-CRD galectin tandem duplication would have given rise to the F4-CRD-linker-F4CRD organization of the Bi-CRD CiLgals-b. However, since the CiLgals-a can be assumed as orthologous to $S$. purpuratus, B. floridae and vertebrate galectins, a deuterostome Bi-Galectin lineage could be hypothesized. Although the CiLgals-b (F4-CRD-F4-linker-CRD) is outside the CiLgals-a group it is orthologous to the A. clava monoCRD gal 16 supporting duplication events from a mono-CRD galectin.

The homology modeling process showed that the CiLgals-a NCRD and C-CRD as well as the CiLgals-b can be superimposed to human C-CRDs and N-CRDs showing a common structural model that include two anti-parallel $\beta$-sheets composed of five and six $\beta$ strands.

The vertebrate galectin signature sequence is directly involved in the galactoside binding. The conservation levels we found suggest that the CiLgals-a N-CRD and C-CRD as well as the CiLgalsb N-CRD signatures are suitable for binding to $\beta$-galactosides. On the contrary, the CiLgals-b C-CRD is so divergent that the signature sequence could not be suitable as sugar binding motif. Such a difference could be related to a distinct functional role.

It is known that galectins form dimers or higher oligomers stabilized by hydrophobic or electrostatic interactions that correlate to their biological roles [6]. Although the galectin oligomeric organization was not a target of the present paper, some indications came from western blot analysis carried out to ascertain that proteins with CiLgals epitopes were contained in the pharynx extract preparations. First we ascertained the specificity of the antibodies produced using peptides properly selected from the mature CiLgals-a and CiLgals-b sequences. The antibodies were selectively purified and assayed for their specificity by competitive ELISA, in addition a Coomassie staining showed that the two recognized bands were not the most represented so as to cause unspecific recognition. The antibodies identified two proteins of different sizes suggesting that CiLgals-a and CiLgals-b are composed of subunits ( $42-38 \mathrm{kDa}$, respectively) that could form oligomers as indicated by 73 and $70 \mathrm{kDa}$ bands. The endurance of oligomers (presumably dimers) in the electrophoretic pattern after denaturating treatments could be due to a partial denaturation attributable to a competition between protein-protein and protein-detergent interactions [27]. Protein-protein interactions in CiLgals oligomerization is an intriguing question that merits further 

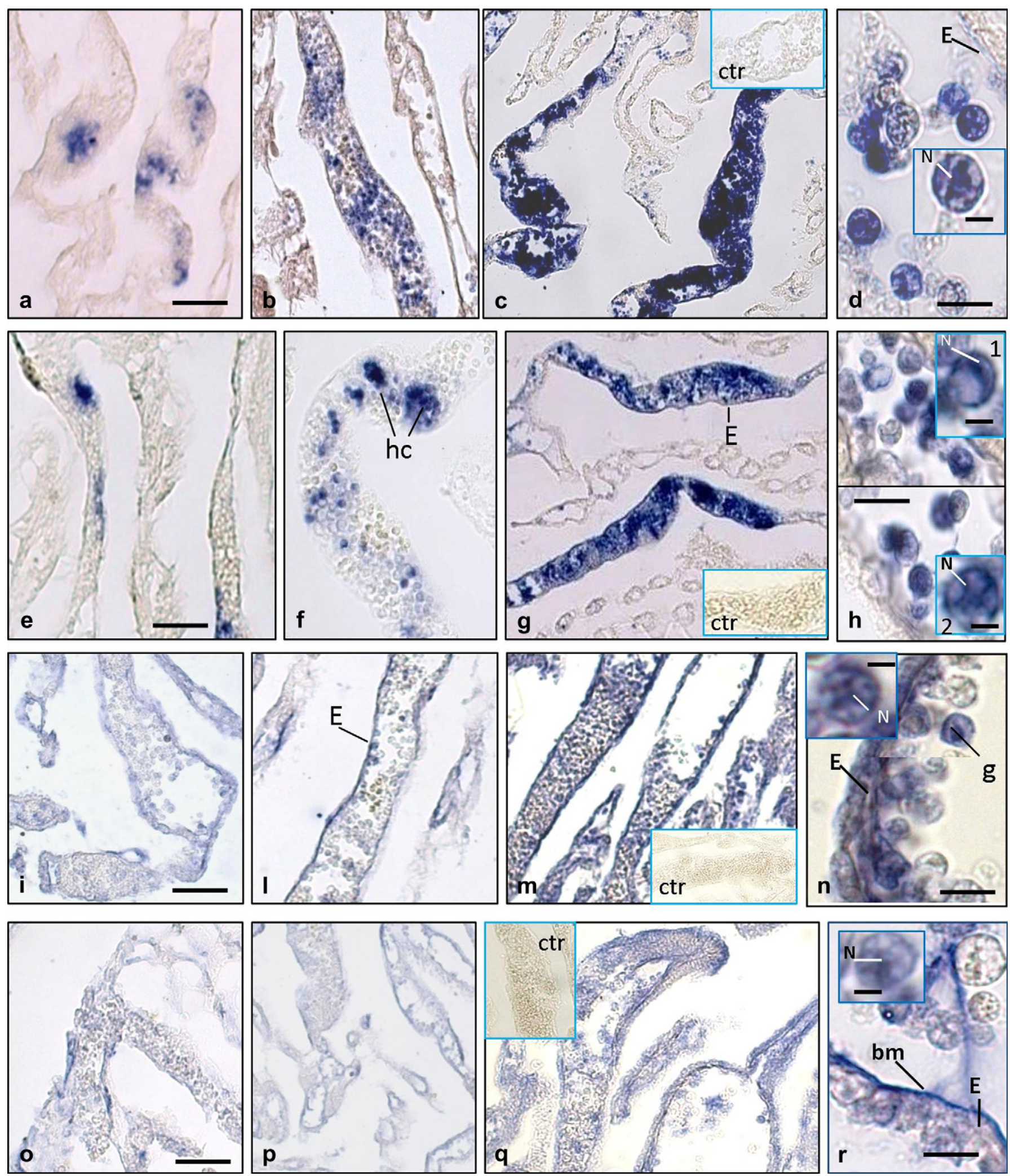

Fig. 5. Histological sections from C. intestinalis pharynx. In situ hybridization with CiLgals-a (a-d) and CiLgals-b (e-h) ripoboprobe. (a, e): sham ascidian at $24 \mathrm{~h}$ after inoculation with marine solution; ascidians at $4 \mathrm{~h} \mathrm{(b,f)} \mathrm{and} 24 \mathrm{~h} \mathrm{(c,g)} \mathrm{time} \mathrm{points} \mathrm{after} \mathrm{LPS} \mathrm{inoculation;} \mathrm{positive} \mathrm{hemocytes} \mathrm{at} 24 \mathrm{~h}$ (d, h): compartment cells (inset in d and inset 2 in h), univacuolar hemocyte (inset 1 in $\mathrm{h}$ ); Immunohistochemistry with anti-CiLgals-a (i-n) and anti-CiLgals-b (o-r) antibody. (i, o): sham ascidian at $24 \mathrm{~h}$ after inoculation with marine solution; ascidians at $4 \mathrm{~h}(\mathrm{l}, \mathrm{p})$ and $24 \mathrm{~h}(\mathrm{~m}, \mathrm{q})$ time points after LPS inoculation; hemocytes at $24 \mathrm{~h} \mathrm{(n,} \mathrm{r):} \mathrm{compartment} \mathrm{cells} \mathrm{in} \mathrm{insets.} \mathrm{Ctr:} \mathrm{control.} \mathrm{E:} \mathrm{epithelium;} \mathrm{hc:} \mathrm{hemocyte}$ clusters; N: nucleus; g: granule; and bm: basal membrane. Bars $100 \mu \mathrm{m}$ (a, b, c, e, f, g i, l, m, o, p, and q), $10 \mu \mathrm{m}$ (d, h, n, and r), insets $5 \mu \mathrm{m}$. 


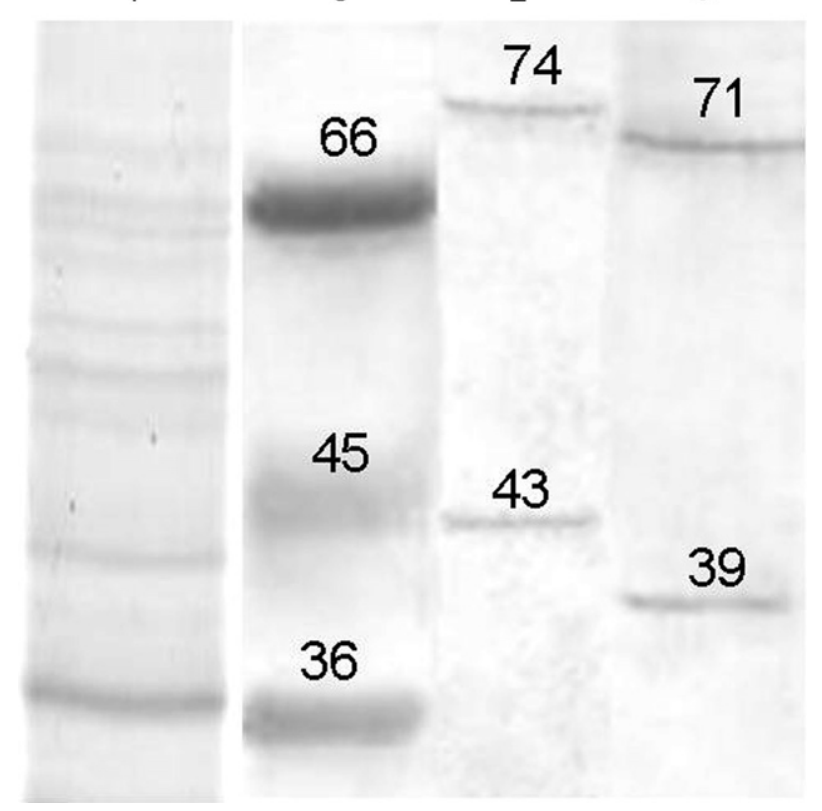

Fig. 6. Western blotting analysis of $C$. intestinalis pharynx homogenate supernatant prepared at $24 \mathrm{~h}$ after LPS inoculation. Gels were calibrated with Sigma-Marker (s): (from top to bottom: albumine bovine serum (66 kDa), ovalbumin from chicken egg (45 kDa), glyceraldehyde-3 phosphate dehydrogenase from rabbit muscle $(36 \mathrm{kDa}))$. The blotted sheets (three distinct samples) were treated with anti-CiLgalsa (1) and -CiLgals-b (2) purified antibodies.

investigation. Furthermore, migration on SDS-PAGE not always correlate with formula molecular weights and gel shift behavior could originate in altered detergent binding and intrachain $S-S$ bridge [40-42].

To ascertain the immunological role of ascidian Bi-galectins, we faced the question about whether and how galectin genes expression could be induced by LPS inoculation. Both the galectins are expressed at a low level by the pharynx of naïve ascidians, the level of mRNA expression increases as an effect of the medium inoculation, but further increases (significantly compared to sham specimens) following an LPS inoculation. Lipopolysaccharides (LPS) are large molecules which act as endotoxins eliciting strong immune responses. It is known that during a pathogenic infection, the expression of galectin genes is often upregulated and their production increase $[2,4]$. The LPS locally inoculated through the ascidian body wall directly permeates the underlying pharynx tissue and stimulates a prompt local inflammatory reaction including upregulation of collagen-IX-like, C3a [43], TNFalfa-like $[23,24]$ and MBL-like genes [25], together with enhanced phenoloxidase activity $[22,44]$ and an overproduction of galectin-like molecules with opsonic properties found in the hemolymph [27]. Here we show that LPS promptly upregulates CiLgals-a and -b genes being CiLgals-a more represented as shown by a higher expression rate. Although we do not know their precise role in ascidian inflammation, according to a previous paper [27] the possibility exists that galectins could exert opsonizing activity. Due to the differences between signature sequences that are involved in sugar binding, the possibility exists that CiLgals-b has a minor role in pharynx inflammatory response as also indicated by the minor immunohistochemical staining with anti-CiLgals-b antibody. Finally, it is of interest that galectins may have an activity as danger signals (alarmins) in inflammatory responses [4].

Hemocytes inside the pharynx vessels are engaged in the galectins expression. According to Arizza and Parrinello [35] inflammatory hemocytes, presumably at various differentiation stages, were marked by the riboprobes and the antibodies. Cell features suggest that compartment cells (variable number of large round globules) and unilocular granulocytes (signet-ring-like) are mainly active in galectin production. These cell types are known to populate the inflamed tissue being engaged in producing and releasing several inflammatory factors $[21,24-26,35]$. The riboprobe localization appears to be coincident with the presumptive location of the nucleus [35] as well as in the cytoplasm close to the vacuoles. The proteins were associated to the outer band of the nucleus and to the vacuolar envelope. Finally both the galectins could be components of the basal membrane of the endothelium.

According to Arizza and Parrinello [35], vacuolated cells and in particular compartment cells in the ascidian inflamed pharynx could represent terminal stages of distinct cell lines differentiated from proliferating stem cells to produce several inflammatory molecules including galectins.

\section{Acknowledgments}

This work was supported by a research grant from the Italian Ministry of Education (PRIN 2006 to N. Parrinello), co-funded by the University of Palermo. We thank Mr. G. Miceli for collecting ascidians and Mr. M. Guarcello for expert maintenance of the aquaria.

\section{References}

[1] Drickamer K, Taylor ME. Biology of animal lectins. Annu Rev Cell Biol 1993;9: 237-64.

[2] Klyosov AA. Galectins and their functions in plain language. In: Klyosov AA, Witczak ZJ, Platt D, editors. Galectins. Hoboken, NJ: Wiley \& Sons; 2008. p. 9-32.

[3] Yu Y, Yuan S, Yu Y, Huang H, Feng K, Pan M, et al. Molecular and biochemical characterization of galectin from amphioxus: primitive galectin of chordates participated in the infection processes. Glycobiology 2007;17:774-83.

[4] Sato S, Rabinovich GA. Galectins as danger signals in host-Pathogen and hosttumor interactions: new members of the growing group of "alarmins"? In: Klyosov AA, Witczak ZJ, Platt D, editors. Galectins. Hoboken, NJ: Wiley \& Sons 2008. p. $115-45$.

[5] Vasta GR, Ahmed H, Odom EW. Structural and functional diversity of lectin repertoires in invertebrates, protochordates and ectothermic vertebrates. Curr Opin Struct Biol 2004;14:617-30.

[6] Nesmelova IV, Dings RPM, Mayo KH. Understanding galectin structure. Function relationships to design effective antagonists. In: Klyosov AA Witczak ZJ, Platt D, editors. Galectins. Hoboken, NJ: Wiley \& Sons; 2008. p. 33-70.

[7] Liu FT, Hsu DK, Yang RY, Chen HY, Saegusa J. Galectins in regulation of inflammation and immunity. In: Klyosov AA, Witczak ZJ, Platt D, editors. Galectins. Hoboken, NJ: Wiley \& Sons; 2008. p. 97-114.

[8] Swalla BJ, Cameron CB, Corley LS, Garey JR. Urochordates are monophyletic within the deuterostomes. Rev Syst Biol 2000;49:52-64.

[9] Zeng L, Swalla BJ. Molecular phylogeny of the protochordates: chordate evolution. Can J Zool 2005;83:24-33.

[10] Delsuc F, Brinkmann H, Chourrout D, Philippe H. Tunicates and not cephalochordates are the closest living relatives of vertebrates. Nature 2006;439: 965-8.

[11] Tsagkogeorga G, Turon X, Hopcroft RR, Tilak MK, Feldstein T, Shenkar N, et al. An updated 18S rRNA phylogeny of tunicates based on mixture and secondary structure models. BMC Evol Biol 2009;5:9-187.

[12] Green PL, Nair SV, Raftos DA. Secretion of a collectin-like protein in tunicates enhanced during inflammatory responses. Dev Comp Immunol 2003;27:3-9.

[13] Shida K, Terajima D, Uchino R, Ikawa S, Ikeda M, Asano K, et al. Hemocytes of Ciona intestinalis express multiple genes involved in innate immune host defense. Biochem Biophys Res Commun 2003;302:207-18.

[14] Azumi K, De Santis R, De Tomaso A, Rigoutsos I, Yoshizaki F, Pinto MR, et al. Genomic analysis of immunity in a urochordate and the emergence of the vertebrate immune system: "waiting for Godot". Immunogenetics 2003;55: $570-81$.

[15] Terajima D, Yamada S, Uchino R, Ikawa S, Ikeda M, Shida K, et al. Identification and sequence of seventy-nine new transcripts expressed in hemocytes of Ciona intestinalis, three of which may be involved in characteristic cell-cell communication. DNA Res. 2003;10:203-12.

[16] Vasta G, Jeffrey C, Hunt J, Marchalonis J, Wayne W. fish galactosyl-binding lectins from the tunicate Didemnum candidum: purification and physicochemical characterization. J Biol Chem 1986;261:9174-81. 
[17] Houzelstein D, Goncalves IR, Fadden AJ, Sidhu SS, Cooper DNW, Drickamer K, et al. Phylogenetic Analysis of the Vertebrate Galectin Family. Mol Biol Evol 2004;21:1177-87.

[18] Parrinello N, Patricolo E, Canicattì C. Inflammatory-like reaction in the tunic of Ciona intestinalis (Tunicata). Encapsulation and tissue injury I. Biol Bull 1984; 167:229-37.

[19] Parrinello N, Patricolo E, Canicattì C. Inflammatory-like reaction in the tunic of Ciona intestinalis (Tunicata). Encapsulation tissue injury II. Biol Bull 1984;167: 238-50.

[20] Parrinello N. The reaction of Ciona intestinalis L. To subcuticular erythrocyte and protein injection. Dev Comp Immunol 1981;5:105-10.

[21] Vizzini A, Pergolizzi M, Vazzana M, Salerno G, Di Sano C, Macaluso P, et al. FACIT collagen (1alpha-chain) is expressed by hemocytes and epidermis during the inflammatory response of the ascidian Ciona intestinalis. Dev Comp Immunol 2008;32:682-92.

[22] Cammarata M, Arizza V, Ciancialo C, Parrinello D, Vazzana M, Vizzini A, et al. The prophenoloxidase system is activated during the tunic inflammatory reaction of Ciona intestinalis. Cell Tissue Res 2008;333:481-92.

[23] Parrinello N, Vizzini A, Arizza V, Salerno G, Parrinello D, Cammarata M, et al. Enhanced expression of a cloned and sequenced Ciona intestinalis TNFalphalike (CiTNF alpha) gene during the LPS-induced inflammatory response. Cell Tissue Res 2008;334:305-17.

[24] Parrinello N, Vizzini A, Salerno G, Sanfratello MA, Cammarata M, Arizza V, et al. Inflamed adult pharynx tissues and swimming larva of Ciona intestinalis share CiTNF alpha-producing cells. Cell Tissue Res 2010;341:299-311.

[25] Bonura A, Vizzini A, Salerno G, Parrinello N, Longo V, Colombo P. Isolation and expression of a novel MBL-like collectin cDNA enhanced by LPS injection in the body wall of the ascidian Ciona intestinalis. Mol Immunol 2009;46:2389-94.

[26] Bonura A, Vizzini A, Salerno G, Parrinello D, Parrinello N, Longo V, et al. Cloning and expression of a novel component of the CAP superfamily enhanced in the inflammatory response to LPS of the ascidian Ciona intestinalis. Cell Tissue Res 2010;342:411-21.

[27] Parrinello N, Arizza V, Cammarata M, Giaramita FT, Pergolizzi M, Vazzana M, et al. Inducible lectins with galectin properties and human IL1alpha epitopes opsonize yeast during the inflammatory response of the ascidian Ciona intestinalis. Cell Tissue Res 2007;329:379-90.

[28] Thompson JD, Higgins DG, Gibson TJ. Clustal W: improving the sensitivity of progressive multiple sequence alignment through sequence weighting, position-specific gap penalties and weight matrix choice. Nucleic Acids Res 1994;22:4673-80.
[29] Thompson JD, Gibson TJ, Plewniak F, Jeanmougin F, Higgins DG. The CLUSTAL_X windows interface: flexible strategies for multiple sequence alignment aided by quality analysis tools. Nucleic Acids Res 1997;25:4876-82.

[30] Guex N, Peitsch MC. SWISS-MODEL and the Swiss-PdbViewer: an environment for comparative protein modeling. Electrophoresis 1997;18:2714-23.

[31] Arnold MS, Green AA, Hulvat JF, Stupp SI, Hersam MC. Sorting carbon nanotubes by electronic structure using density differentiation. Nat Nanotechnol 2006;1:60-5.

[32] Schwede T, Kopp J, Guex N, Peitsch MC. SWISS-MODEL: an automated protein homology-modeling server. Nucleic Acids Res 2003;31:3381-5.

[33] Plagemann PG. Epitope specificity of monoclonal antibodies to the N-protein of porcine reproductive and respiratory syndrome virus by ELISA with synthetic peptides. Vet Immunol Immunopathol 2005;104:50-68.

[34] Laemmli UK. Cleavage of structural protein during the assembly of the head of bacteriophage T4. Nature 1970;227:680-5.

[35] Arizza V, Parrinello D. Inflammatory hemocytes in Ciona intestinalis innate immune response. Invertebr Survival J 2009;6:58-66.

[36] Bradford MM. A rapid and sensitive method for the quantitation of microgram quantities of proteins utilizing the principles of protein-dye binding. Anal Biochem 1976;72:248-54.

[37] Cooper DNW, Barondes SH. God must love galectins: he made so many of them. Glycobiology 1990;9:979-84.

[38] Nickel W. The mystery of nonclassical protein secretion. A current view on cargo proteins and potential export routes. Eur J Biochem 2003;270: 2109-19.

[39] Liu FT. Regulatory roles of galectins in the immune response. Int Arch Allergy Immunol 2005;136:385-400.

[40] Shirahama K, Tsujii K, Takagi T. Free-boundary electrophoresis of sodium dodecyl sulfate-protein polypeptide complexes with special reference to SDSpolyacrylamide gel electrophoresis. J Biochem 1974;75:309-19.

[41] Janin J, Miller S, Clothia C. Surface, subunit interfaces and interior of oligomeric proteins. J Mol Biol 1988;204:155-64.

[42] Rath A, Glibowicka B, Nadeau VB, Chen G, Deber CM. Detergent binding explains anomalous SDS-PAGE migration of membrane proteins. PNAS 2009; 106:1760-5.

[43] Pinto MR, Chinnici CM, Kimura Y, Melillo D, Marino R, Spruce LA, et al. CiC3-1a mediated chemotaxis in the deuterostome invertebrate Ciona intestinalis (Urochordata). J Immunol 2003;171:5521-8.

[44] Cammarata M, Parrinello N. The ascidian prophenoloxidase activating system. Invertebr Survival J 2009;6:S67-76. 